\title{
THE APPLICATION OF CYCLOSTRATIGRAPHY AND ASTROCHRONOLOGY IN THE NEOGENE MARINE DEPOSITS OF EASTERN MEDITERRANEAN: METOCHIA SECTION (GAVDOS ISLAND)*
}

\author{
A. Antonarakou', H. Drinia ${ }^{1} \&$ F. Pomoni-Papaioannou ${ }^{1}$ \\ ${ }^{1}$ National and Kapodistrian University of Athens, Faculty of Geology and Geoenvironment, Department \\ of Historical. Geology-Paleontology, Panepistimiopolis, Zografou, aantonar@geol.uoa.gr
}

\begin{abstract}
Significant lithostratigraphical and micropaleontological signatures, of Milankovitchscale climatic changes are recorded in Miocene deep-sea sediments. As a case study, the Metochia Section, in Gavdos Island, which covers the time interval from 9.7 to $6.6 \mathrm{Ma}$, is used. This study emphasizes the sedimentological and micropaleontological characteristics of the section, attributed to Milankovitch-scale climatic changes.

The short-term variations in climate and faunal composition are related to precession-controlled sedimentary cycles and the long-term trend in climate is related to eccentricity and obliquity cycles. Regional changes in sea surface temperature in combination with variations of solar insolation have caused the cyclical astronomical controlled pattern of Globorotalia species.
\end{abstract}

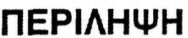

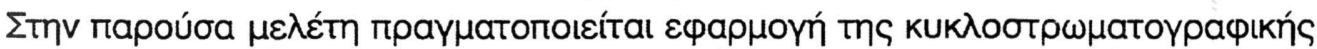

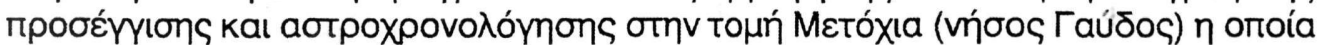

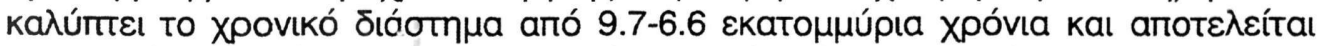

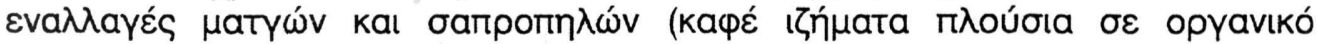

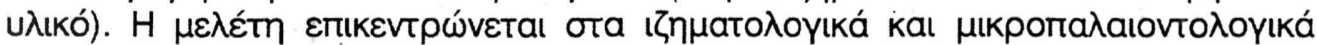

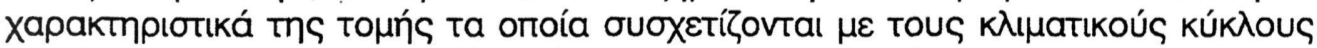

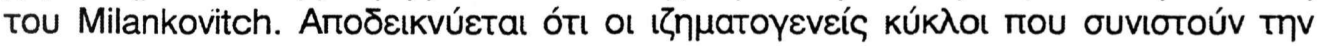

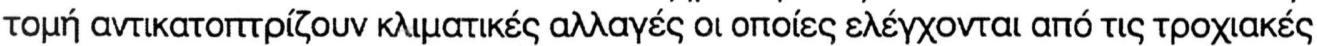

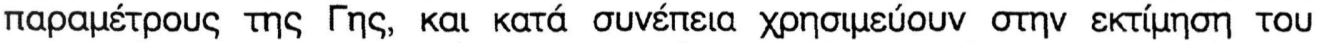

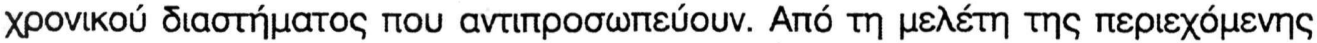

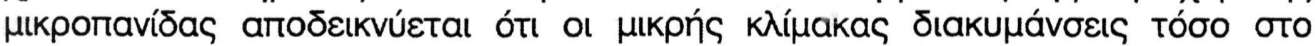

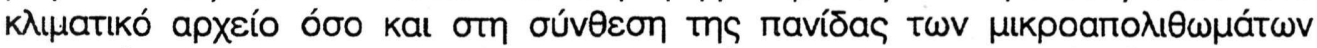

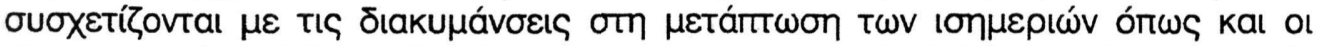

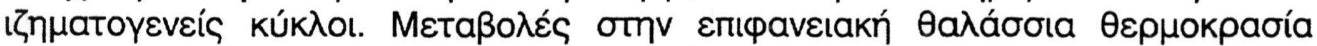

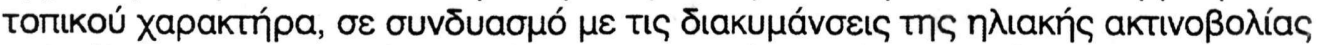

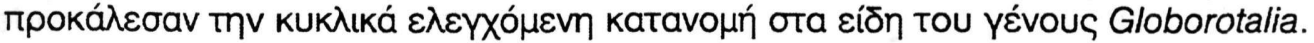

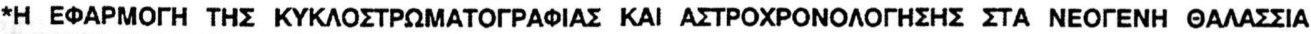

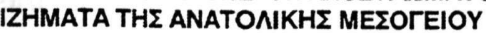

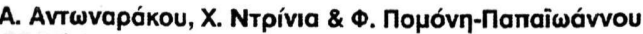

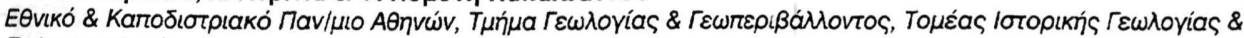

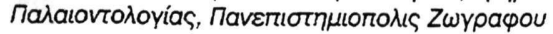




\section{Introduction}

In the Eastern Mediterranean sendimentary record, since Last Glacial Maximum, major and minor climate changes are amplified and perfectly preserved, as for example, the deglaciation itself, the Younger Dryas cold episode and the Holocene climatic optimum.

Evidence concerning the Mediterranean climate is available from historical and fossil records and several signatures of the Eastern Mediterranean Sea evolution have been detected. However, part from geodynamical evolutions which refer to large time-scale (million years), in the sedimentary record includes significant signatures of past changes in climate, hydrology, fauna, oxygen, and biological production (e.g. the peculiar example of the sapropel layers over the last half million years (Bethoux, 1993). It is now over twenty years since it was first demonstrated that orbital cycles are preserved in the climatic records of deep-sea sediments (Shackleton \& Opdyke, 1973; Hays et al., 1976).

There are clear and distinct effects of orbital parameters (obliquity, eccentricity, and precession) on intermediate to short-term climate change. Orbital climate forcing is an important control on variation in sediment supply, because orbital parameters have a marked effect on the seasonality of incoming solar radiation (insolation), which results in variations in the seasonality of rainfall. As a result, orbital climate forcing plays a major role in sedimentation and stratigraphy.

The Miocene basins of eastern Mediterranean have been developed in geographic latitude roughly $35^{\circ}$, which intensely received the effects of climatic fluctuations, due to the differentiations of the orbital behaviour of the Earth. These climatic oscillations, cycles, are clearly reflected in sedimentary cycles and an excellent example is the Milankovitch cyclicity of the prodelta turbidites, of the Eastern Mediterranean Basin, since the early Late Miocene (Postma et al., 1993) and early Pliocene (Weltje \& De Boer, 1993).

These turbidites arise in successions of alternating hemipelagic (bioturbated marls) and sapropelic (lam-initic) sediments, the latter being a mixture of welllayered siliciclastic and organic material. According to Krijgsman et al. (1995) and Hilgen et al. (1995), the origin of the laminate marl couplets is due to astronomical forcing, in view of the fact that the occurrence and thickness of the sapropelic layer are roughly correlatable with the insolation curve of Laskar et al. (1993), (Fig. 1).

Rohling (1994) stated that the abundance of preserved organic material in the sapropels can be attributed to a combination of anoxic conditions at the sea bottom on the one hand and high organic production on the other. Moreover, Van der Zwaan \& Gudjonsson (1986), in their work concerning stable isotopes on planktonic foraminifera, demonstrated that sapropel formation was simultane with periods of increased continers, iun off. Prell \& Kutzbach (1987) anc rilgen (1991) correlated the latter periods with an intensified Indian Ocean SW summer monsoonal system, influencing the eastern Mediterranean via the Nile River and by increased continental activity of Mediterranean depressions as an element of the westerly Atlantic system.

Conclusively, the sapropels provide important clues concerning the origin, the timing and the duration of climate-related turbidite deposition in this basin.

A case study, which represents the afore- 
mentioned assumptions is the Metochia (Krijgsman et al., 1995; Antonarakou, section, in Gavdos Island, which covers 2001) (Fig. 2, 3). In the present paper, the time interval from 9.7 until $6.6 \mathrm{Ma}$ we attempt to highlight the intimate

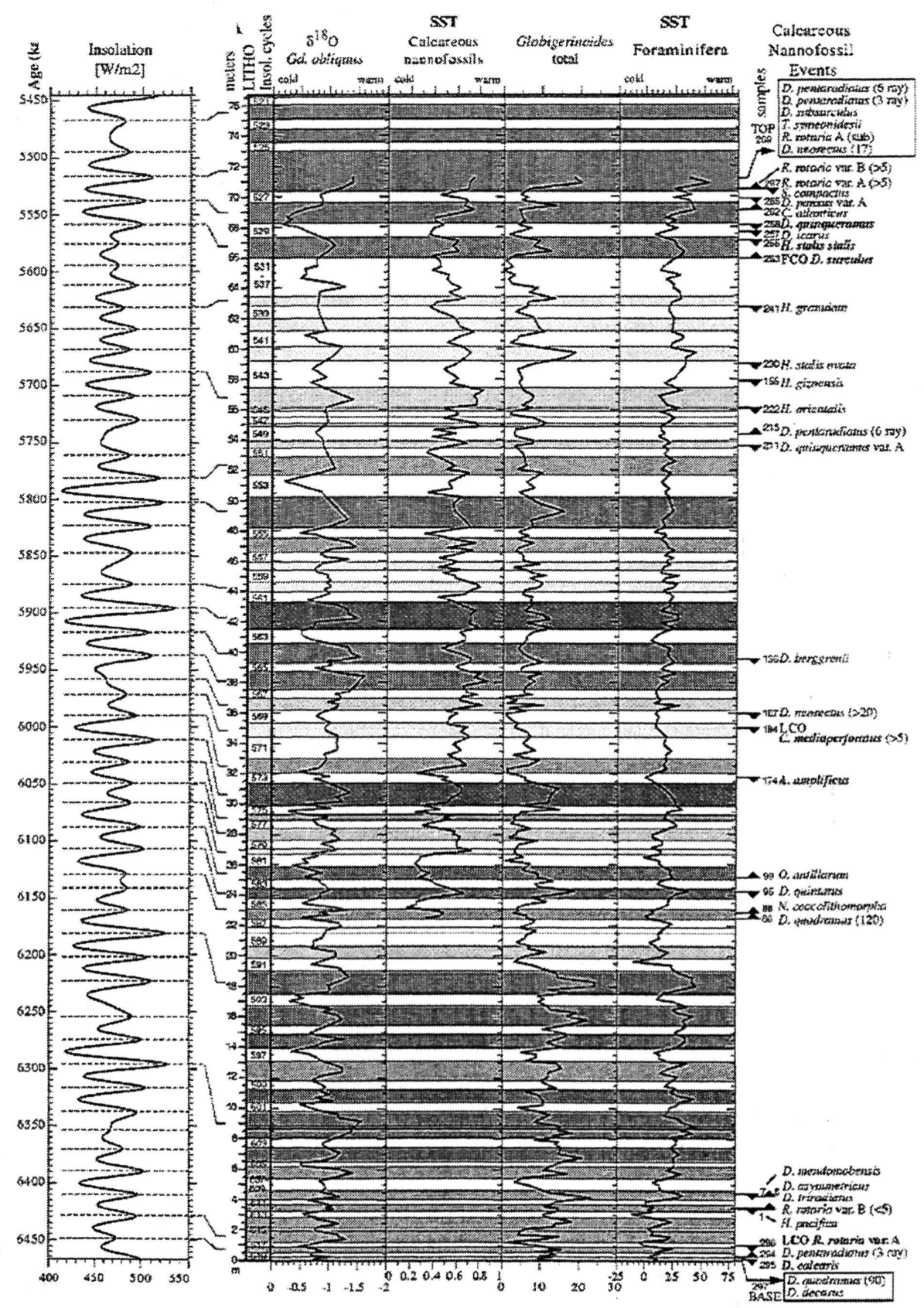

Fig. 1. Insolation curve of Laskar et al. (1993) 


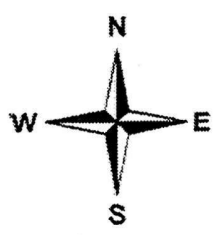

\section{GAVDOS ISLAND}

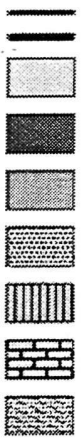

Fault

Thrust zone

Limestone crusts, sand, gravel etc.

Pleistocene

Pre-Neogene

Basal conglomerate

Fossiliferous sandstones

Maris and turbidites

Bioclastic limestones

Alternations of maris and sapropels with turbidites and diatomites

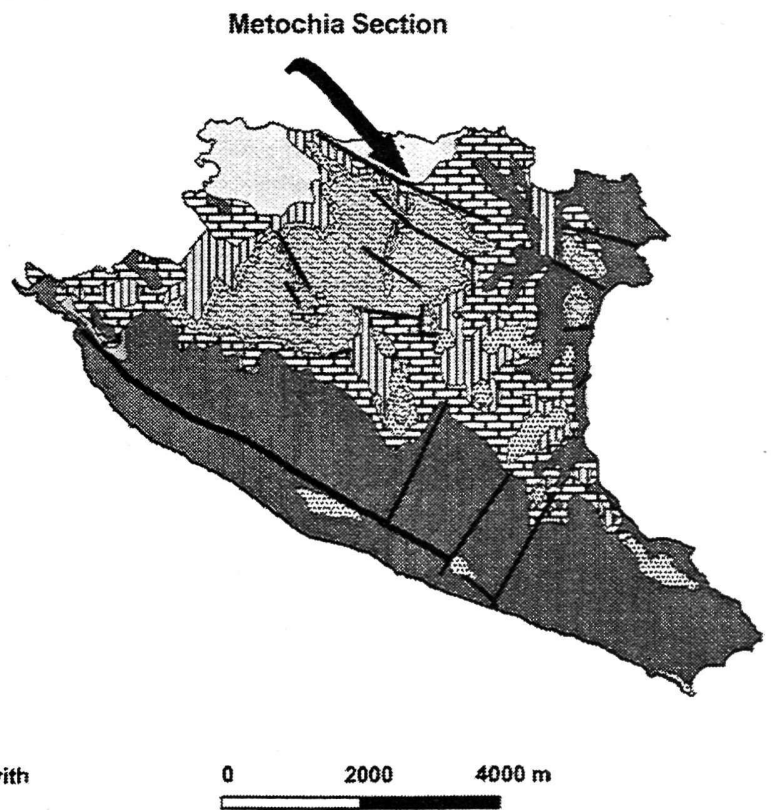

Fig. 2. Geological map of Gavdos Island, indicating the location of the Metochia section.

relation of the sedimentological and micropaleontological characteristics of the section, with the Late Miocene Milankovitch-scale climatic changes.

\section{Lithostratigraphic Signal}

Metochia section, a Late Miocene hemipelagic marl succession, is located at the northeast part of the Gavdos Island and contains 96 (L1 to L96) rhythmic alternations of poorly to non bioturbated brown-grey, organic-rich laminated beds (the so called "sapropels") and bioturbated, light grey-blue, homogeneous, hemipelagic marl beds (Fig. 3), deposited in approximately $850 \mathrm{~m}$ water depth (Postma et al. 1993). The sapropelic intervals become dominated by sandy turbidites from L7-13 (Fig. 3). The turbidite sequences are characterized by multiple events of thinly bedded, wedging turbidites, each turbidite sequence being covered by a marl layer. For instance, the L7 turbidite succession (Fig. 4) contains at least 100 separate turbidite events recorded as thinly layered fine sandy to silty turbidites ranging in thickness from 0.5 to $3 \mathrm{~cm}$. The fine-grained intervals have a typical brown to yellow colour and contain organic plant material, which contrasts markedly with the blue-grey colours of the overlying homogeneous, hemipelagic marl interval. Turbidite 
Bulletin of the Geological Society of Greece, vol. XXIX/I, 17-27

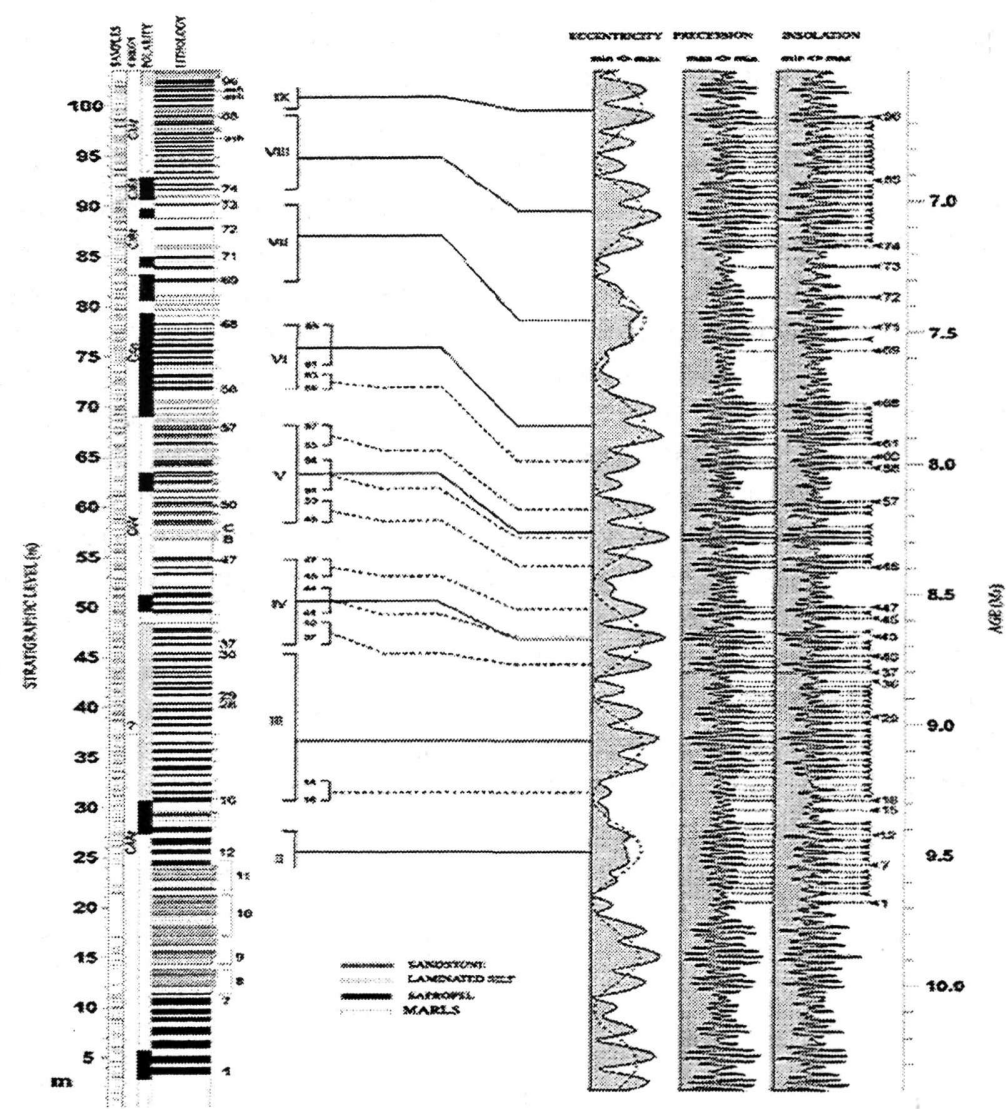

Fig. 3. Lithostratigraphical column of the Metochia Section and age time control derived from the astronomical calibration of the sedimentary cycles and planktonic foraminifera bioevents.

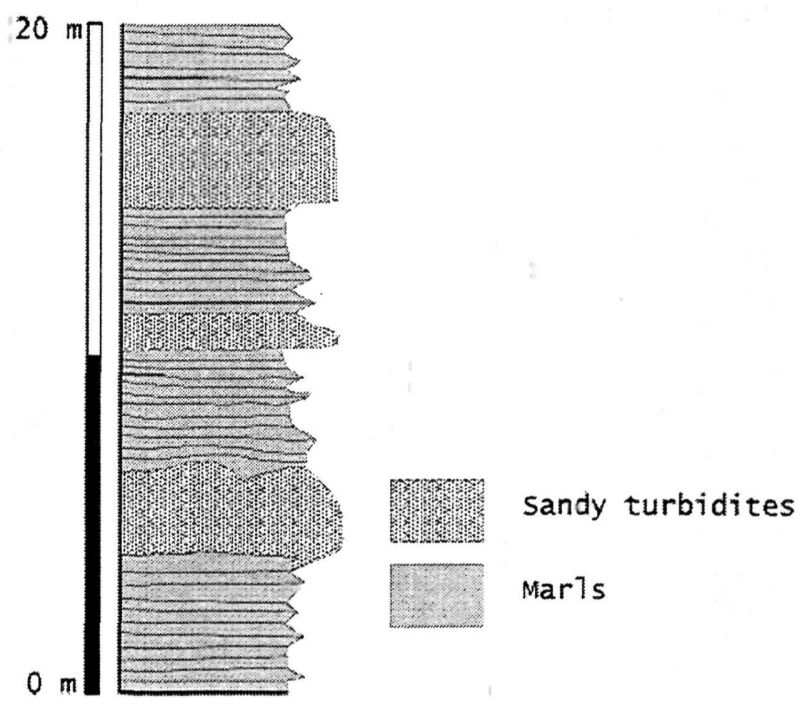

Fig. 4. The $L 7$ turbidite succession. 
sequences L8-L11 display crude thickening and coarsening of upward trend. In the central and upper part of these sequences, the sand/clay ratio increases, with turbidite beds becoming thicker and coarser upwards.

The strong association between turbidites and laminites suggest that growth of the prodelta lobes occurred during precession punctuated periods of increased precipitation and increased run-off. Tectonic tilting, seismic shock and sediment overloading due to sea level lowering are believed to be far less important triggering mechanisms for the L7-L13 turbidites.

The described turbiditic sequence is characterized by fluctuations of the thickness of the turbiditic layers. The absence of channel deposits, the fact that the sequence is coarsening upwards and finally, the lobe geometry of the layers, indicate deposition in relatively small-sized sandy lobes. These lobe deposits were created probably due to local scale palaeoclimatic fluctuations owing to precession and not to glacio-eustatic sea-level fluctuations.

This interpretation is supported:

1 . by the obvious predominance of local scale climatic effects in the Mediterranean. Detailed analysis of the sedimentary record that has been affected by climatic and oceanographic fluctuations, due to precession, showed that they represent changes in the discharge, in the sediment supply and

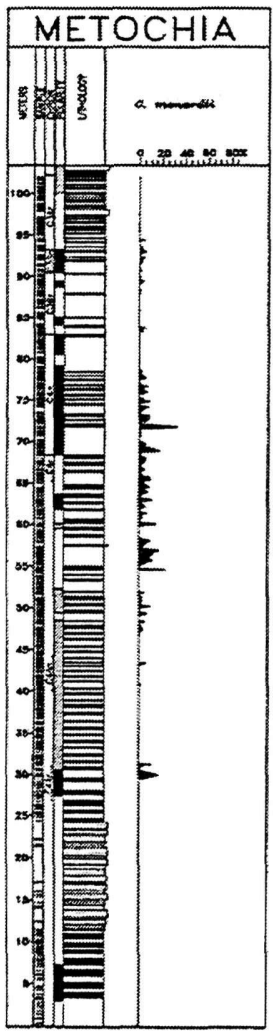

Fig. 5. Distribution pattern of Globorotalia species

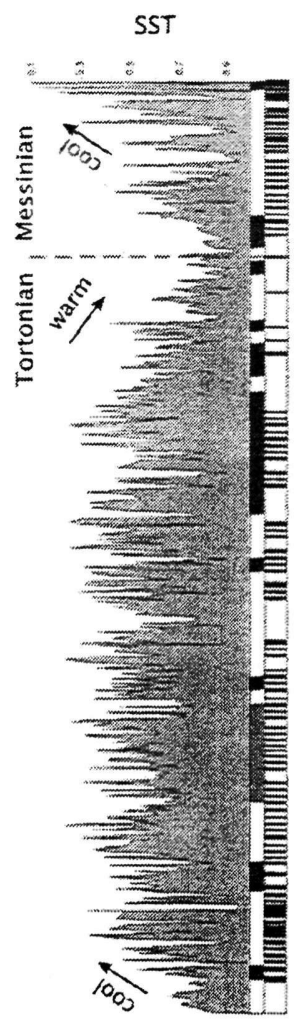

Fig. 6. The SST proxy record of the Metochia section 
in the primary productivity. This fact is well-documented for the Late Miocene and the Lower Pliocene of the central and eastern Mediterranean.

2. by the tectonic setting of the basin which excludes the presence of a shelf, implying that the effect of possible sea level fluctuations in the sediments was of small importance.

On the contrary, the fluctuations in river run-off, which in turn, influence precipitation, constitute the responsible mechanism for the creation of the described turbiditic system. The periodical alternations between relatively dry and humid climatic conditions, with simultaneous change in the flow and in the sediment supply, appear to be the most likely explanation for the creation of this sedimentary setting.

\section{Micropaleontological Signal}

The aforementioned assumptions were further supported by micropaleontological analysis based on planktonic foraminifera.

The distribution pattern of the planktonic foraminifera species identified in the Metochia section has been analyzed and used for the orbital configuration of the climatic changes and the sedimentary cyclicity of the section (Antonarakou, 2001).

According to Antonarakou et al. (2004), one of the most significant events which can be correlated with Millankovitchscale climatic changes is the replacement of the Globorotalia menardii group by the Globorotalia miotumida group, characterizing the Tortonian/Messinian boundary $(7.12 \mathrm{Ma})$.

Due to the fact that during the Miocene,
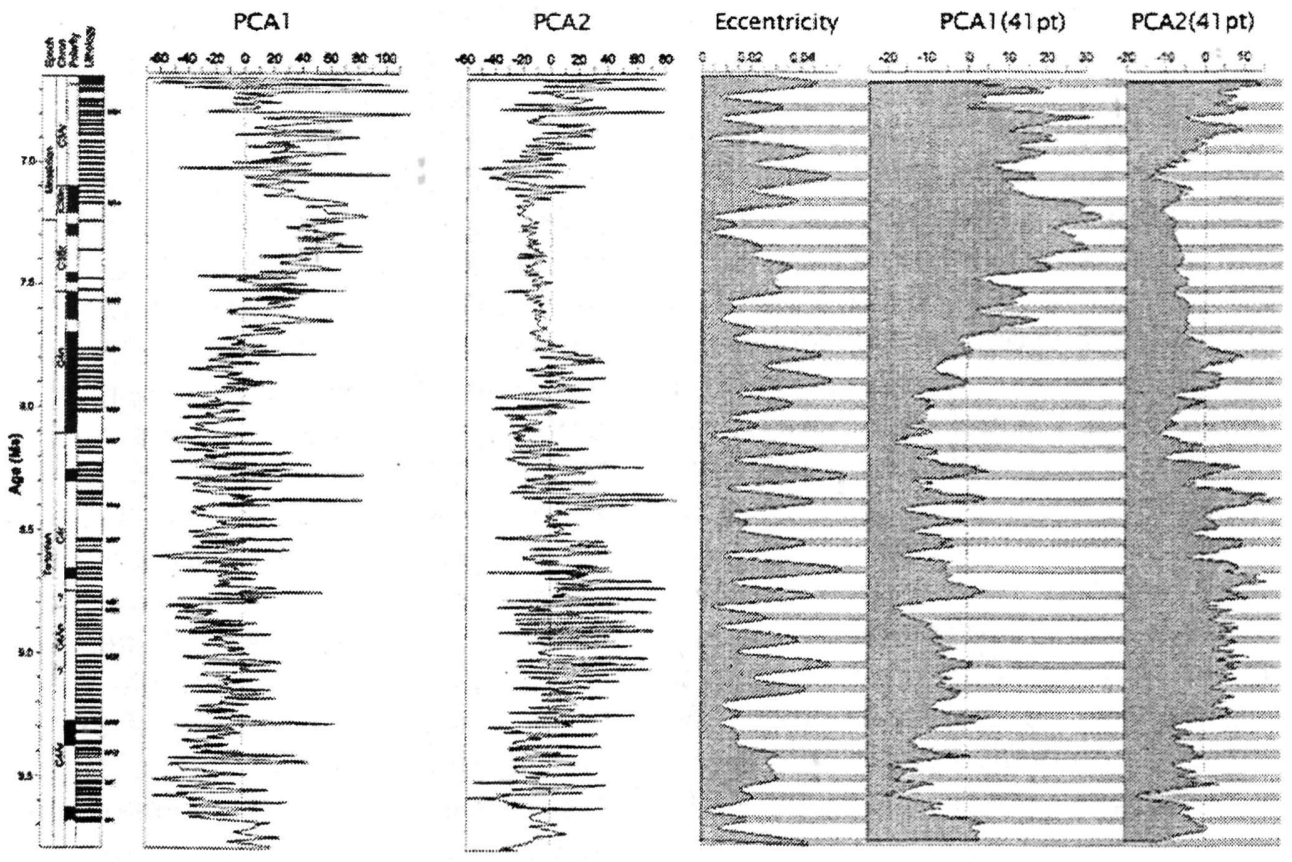

Fig. 7. PCA analysis and correlation to orbital parameter (eccentricity) 
the Globorotalia menardii group was restricted to the tropical and subtropical region, whereas the Globorotalia miotumida group was present in temperate areas, their presence determine different climatic zones (Sierro et al., 1993). The distribution pattern of the keeled globorotaliids throughout the section reveals short-term recurrent variations of the G. menardii group, being presented from the lower part of the section. Whereas, Globorotalia miotumida appears later at the section and marks the Tortonian/Messinian boundary (Fig. 5).

Keeled globorotallids display an intermittent distribution pattern. This holds in particularly for the sinistrally coiled G. menardii 4 in the lower part of the section (cycles L1-L45, 3-53m). This species occurs more regularly between L46-L68 (54-78m) but then vanishes until a short but prominent influx in L69 $(82 \mathrm{~m})$. The top of this brief reoccurrence is equated with the LCO of $G$. menardii 4 (7.5 Ma) even though this species shows a final and extremely brief influx at the upper part of the range of $\mathrm{G}$. menardii 5 . Keeled globorotaliids then become absent again up to the first occurrence (FO-7.3 Ma) level of the right-coiled $G$. menardii 5 directly above the $L 72(88 \mathrm{~m})$. The interval in which $G$. menardii 5 is the dominant keeled globorotaliid is punctuated by a very short but distinct influx of $G$. menardii 4. At about $L 73(90 \mathrm{~m})$, G. menardii 5 is definitively replaced by left-coiled assemblages of keeled globorotaliids, characterized by a reniform chamber outline in spiral view. These assemblages are termed Globorotalia conomiozea group by Zachariasse (1979) and Globorotalia miotumida group by Sierro (1985) and Sierro et al. (1993). The earliest representatives of $G$. conomiozea group show flat tests typical of G. miotumida, while the regular occurrence of the conical types (G. conomiozea) starts in cycle L76 $(92 \mathrm{~m})$.

Variations in their relative abundance reflect variations in sea surface temperatures with $G$. menardii correlated with warmer intervals and $G$. miotumida with cooler intervals. This replacement is used to identify regional short-term climatic fluctuations in the Tortonian / Messinian boundary. This interpretation is further supported by the SST curve based on temperature sensitive species, using the habitat characteristics of all the identified planktonic foraminifera species (Fig. 6).

The Principal Component Analysis applied on the total data set of the containing fauna revealed that PCA 1 variations correspond to Sea Surface Temperature and PCA 2 to the Sea Surface Productivity (SSP curve, Antonarakou et al., 2004) and are correlated to eccentricity cycles. SSP variations reflect the sedimentary cycles for the studied section (Fig. 7).

Both the proxy records of the micropaleontogical characteristics and the statistical analysis suggest that during the Late Miocene, the climate was quite stable. Long-term changes reflected by the abundance fluctuations pattern are determined by a cooling trend, from 9.7 $\mathrm{Ma}$ to $7.6 \mathrm{Ma}$, a warmer period from 7.6 to $7.2 \mathrm{Ma}$ and then a cooling trend which finishes at the Messinian. At 7.6 Ma specimens of $G$. miotumida start to exist but the replacement takes place at $7.2 \mathrm{Ma}$, where the climate seems to be ameliorated. In spite of the fact that all these proxy curves simplify the original and highly complex faunal patterns of the individual taxa, short term variations still remain. To establish both the frequencies of these short-term 
Bulletin of the Geological Society of Greece, vol. XXIX/I, 17-27
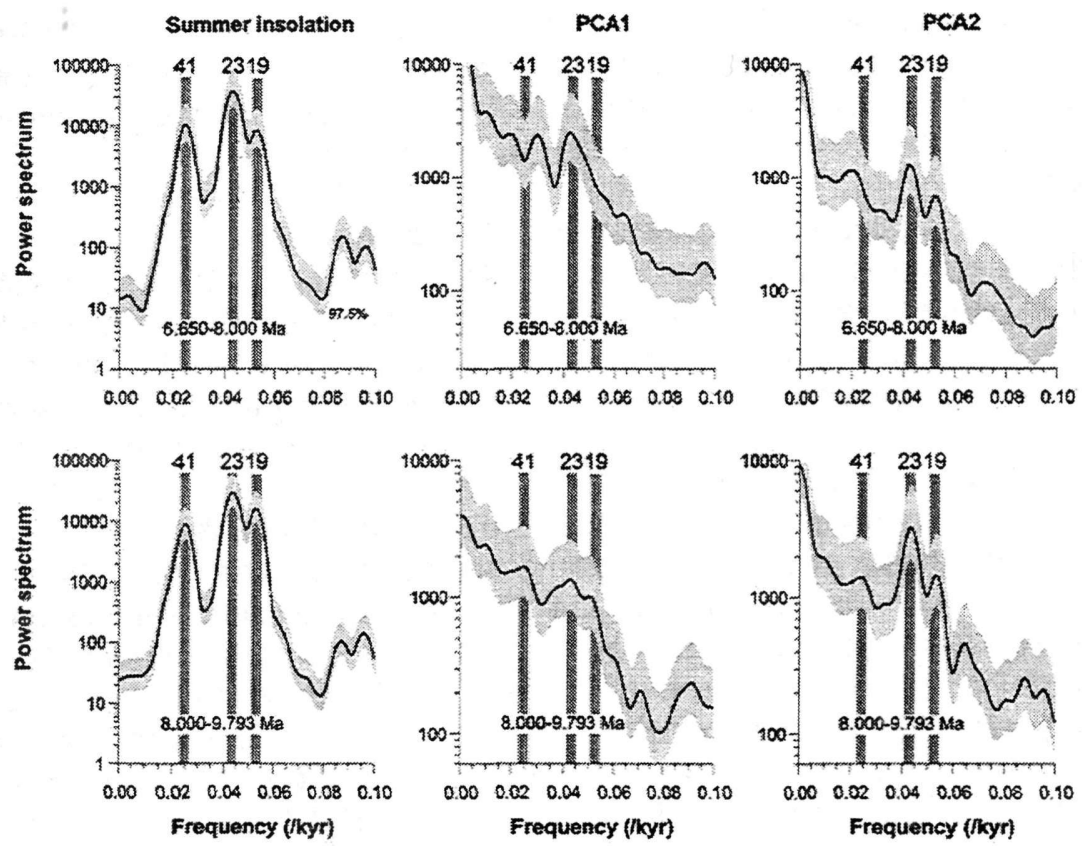

Fig. 8. Spectral analysis on PCA-1 and PCA-2
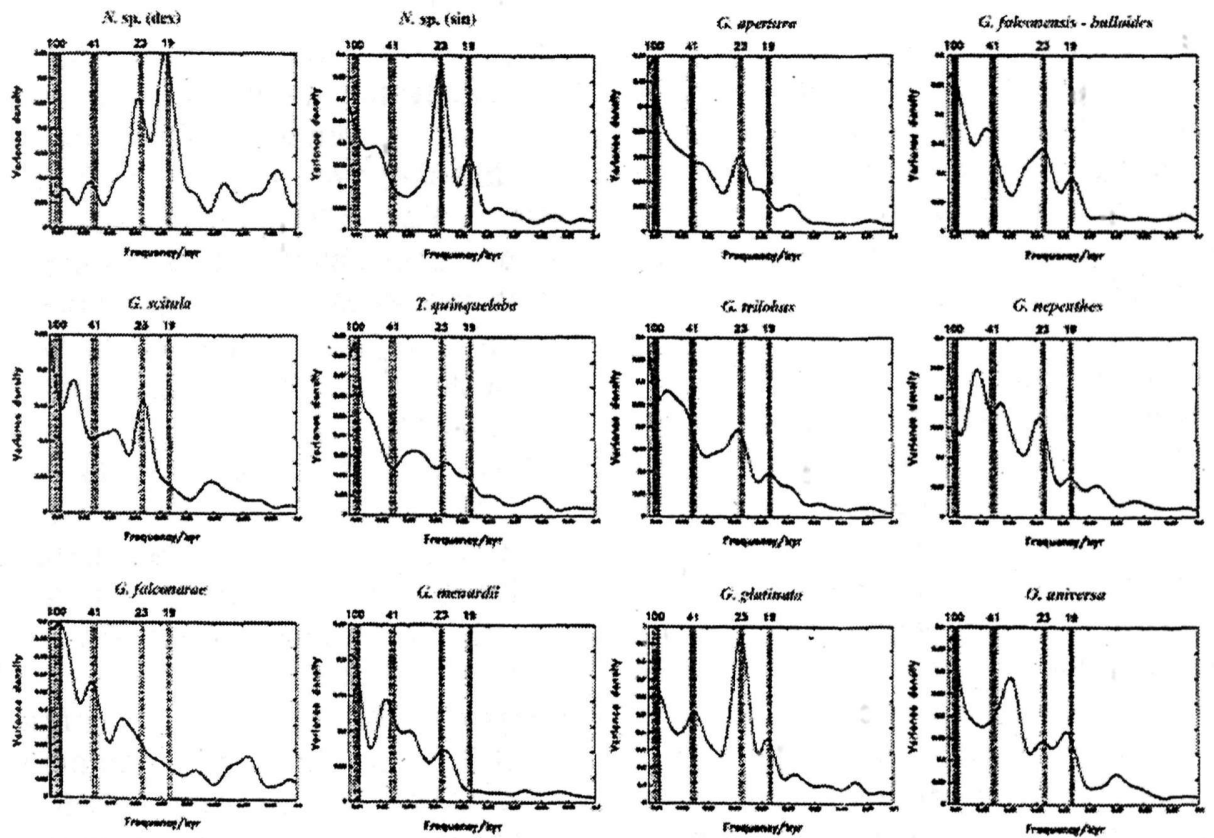

Fig. 9. Spectral analysis of individual species 
variations and the possible influence of astronomical forcing, spectral analysis was performed on the proxy curves on individual taxa based on their quantitative data.

The spectral analysis shows that in Metochia section sedimentary cycles (sapropel cycles) are astronomically forced by precession and eccentricity cycles while sea surface temperature variations are controlled by precession and obliquity variations (Fig. 8). This orbital configuration during sapropel formation indicates strongly seasonal contrast.It is remarkable that, in the studied sequence, for the time interval between 9.7 to $8 \mathrm{Ma}$, sea surface cycles and SST are also related to obliquity cycles. However, this orbital configuration is strongly determined by fluctuations in the distribution of several species (Fig. 9). In particular, the relative abundance fluctuations of $G$. menardii are related to obliquity $(41 \mathrm{Kyr})$ cycles and precession ( $23 \mathrm{kyr}$ ) cycles together with $N$. acostaensis d. G. falconarae and G. glutinata. This is a mixed association of eutrophicate and tropical species. These species are more abundant in the lower part of the section for the time interval 9.7 to $8 \mathrm{Ma}$.

\section{Conclusions}

This work represents a review of the most significant lithostratigraphical and micropaleontological signatures of Milankovitch scale climatic changes overprinted on Late Miocene.

Lithostratigraphical signatures of Milankovitch-scale climate changes are detectable on the Late Miocene section of Metochia, in Gavdos island (an interval between 9.7 to $6.6 \mathrm{Ma}$ ) Identification and documentation of the lithostratigraphic signature was not possible without a detailed. micropaleontological analysis based on planktoni foraminifera which enables us to reconstruct the smallscale climate changes recorded in the studied section.

\section{References}

Antonarakou, A., 2001. Biostratigraphic and paleoenvironmental implications on Miocene sediments of Eastern Mediterranean (Gavdos Island): $P h D$ Thesis, Athens University, 180p.

Antonarakou, A., Drinia, $\mathrm{H}_{\text {., }}$ and J. W., Zachariasse, 2004. Cyclostratigraphic determination of the replacement of Globorotalia menardii group by Globorotalia miotumida group. A significant climatic change signal. Environmental Micropaleontology, Microbiology, Meiobenthology, vol.1, pp. 155-175.

Bethoux, J.P., 1993. Mediterranean sapropel formation, dynamic and climatic viewpoints. Oceanol. Acta, 16, 127-133.

Hays, J.D., J. Imbrie, and N.J., Shackleton, Variations in the earth's orbit: pacemaker of the ice ages, Science, 194, 1121-1131, 1976.

Hilgen, F.J., 1991. Astronomical calibration of Gauss to Matuyama sapropels in the Mediterranean and implication for the Geomagnetic Polarity Time Scale. Earth Planet. Sci. Lett., 104, 226-244.

Hilgen, F.J., Krijgsman, W., Langereis, C.G., Lurens, L.J., Santarelli, A. \& Zachariasse, J.W., 1995. Extending the astronomical (polarity) time scale into the Miocene. Earth Planet. Sci. Lett., 136, 495-510.

Krijgsman, W., Hilgen, F.J., Langereis, C.G., L.J., Lourens, Santarelli, A. \& J.W. Zachariasse, 1995. Late Miocene magnetostratigraphy, biostratigraphy and cyclostratigraphy from the Mediterranean. Earth and 
Planetary Science Letters, 136, 475494.

Laskar, J., Joutel, F., \& Boudin, F., 1993. Orbital, precessional and insolation quantities for the Earth from $20 \mathrm{Ma}$ to $+10 \mathrm{Ma}$. Astron. Astrophys., 270, 522-533.

Postma, G., Hilgen, F.J., \& Zachariasse, W.J., 1993. Precession punctuated growth of a Late Miocene submarine-fan lobe on Gavdos (Greece). Terra Nova, 5, 438-444.

Prell, W.L. \& Kutzbach, J.E., 1987. Monsoon variability over the past 150.000 years. J. Geophys. Res., 92, 8411-8425.

Rohling, E., 1994. Review and new aspects concerning the formation of eastern Mediterranean sapropels. Mar. Geol., 122,1-28.

Shackleton, N.J., and N.D., Opdyke, Oxygen isotope and palaeomagnetic stratigraphy of equatorial Pacific core V28-238: oxygen isotope temperatures and ice volumes on a 10 and 10 year scale, Quat. Res., 3, 39-55, 1973.

Sierro, F.J., 1985. The replacement of the "Globorotalia menardii" group by the "Globorotalia miotumida" group: an aid to recognizing the
Tortonian/Messinian boundary in the Mediterranean and adjacent Atlantic. Marine Micropaleontology, 9(6), 525535.

Sierro, F.J., Flores, J.A., Civis, J., Gonzales Delgado, J.A. \& G. Frances, 1993. Late Miocene globorotaliid event-stratigraphy and biogeography in the NE Atlantic and Mediterranean. Marine Micropaleontology, 21, 143168.

Van der Zwaan, G.J., \& Gudjonsson, L., 1986. Middle Miocene-Pliocene stable isotope stratigraphy and paleoceanography of the Mediterranean. Mar. Micropaleontol., 10, 71-90.

Weltje, G.J., \& De Boer, P.L., 1993. Astronomically induced paleoclimatic oscillations reflected in Pliocene turbidite deposits on Corfu (Greece): implications for the interpretation of higher order cyclicity in ancient turbidite systems. Geology, 21,307-310.

Zachariasse, W.J., 1979. Planktonic Foraminifera from section Potamida I: Taxonomic and phyletic aspects of keeled globorotaliids and some paleoenvironmental estimates. Utrecht Micropaleontological Bulletins, 21, 129-166. 